\title{
Timothy Grass Pollen Sensitization in Asthmatic Egyptian Children
}

\author{
Elham Mohammad Hossny, Hanan Mohamed Abd El Lateef, \\ Ahmed Abd El-Hamid Abd El-Hamid Youssef \\ Department of Pediatrics, Faculty of Medicine, Ain Shams University \\ Corresponding author: Ahmed Abd El-Hamid Abd El-Hamid Youssef, email:ahmedabdelhamidrihan@gmail.com
}

\begin{abstract}
Background: Allergic diseases are considered a major problem for healthcare systems in both developed and developing countries. Longitudinal epidemiologic studies have shown an increased prevalence of sensitization to common allergens, and increased prevalence of asthma, atopic dermatitis, food allergy, and allergic rhinitis in children. The increase in allergies is a phenomenon that is being observed in all fast-developing countries. For a long time, science has taken as a starting point that solely a genetic predisposition is a precondition for the development of an allergy. Today, knowledge of environmental factors that can alter genes or the transcription of genes in the cells, has improved. Aim of the Work: We aimed to investigate the rate of sensitization to Timothy grass pollen in a group of asthmatic Egyptian children in relation to other markers of disease expression. Our ultimate objective was to add information to the map of aeroallergen sensitization in our country. Patients and Methods: This analytical cross sectional study was conducted on children with bronchial asthma following up at the Pediatric Allergy and Immunology Clinic, Children's Hospital, Ain Shams University in the period from September 2017 to March 2018. The sample included 100 asthmatic patients who were enrolled consecutively. Patients were classified into intermittent and persistent Asthma according to the 2009 VA/DoD asthma management guidelines. Results: The current study revealed a high frequency of Timothy grass pollen (TGP) sensitization representing $61 \%$ of the studied sample. The diameter of wheal in sensitized children ranged between 3-7 $\mathrm{mm}$ with a median (IQR) of 4 (3-4). None of our subjects had wheal diameter $\geq 8 \mathrm{~mm}$, which denotes severe reaction. In our study, Patients with persistent asthma were more prone to be TGP sensitized $(80.3 \%)$ than those with intermittent asthma (19.7\%). Sensitized children with persistent asthma showed larger wheal diameter (median $=4 \mathrm{~mm}$, range: $4-7 \mathrm{~mm}$ ) than those with intermittent asthma who showed smaller diameter (median $=3.5 \mathrm{~mm}$, range: $3-4 \mathrm{~mm}$ ). Conclusion: Sensitization to TGP might point a persistent phenotype of pediatric asthma and may be linked to severity and need to step up and/or add on therapeutic options.
\end{abstract}

Keywords: Timothy Grass Pollen Sensitization, Asthmatic Egyptian Children

\section{INTRODUCTION}

Allergic diseases are considered a major problem for healthcare systems in both developed and developing countries (1). Longitudinal epidemiologic studies have shown an increased prevalence of sensitization to common allergens, and increased prevalence of asthma, atopic dermatitis, food allergy, and allergic rhinitis in children ${ }^{(2)}$.

The increase in allergies is a phenomenon that is observed in all fastdeveloping countries for a long time. Science has taken as a starting point that solely a genetic predisposition is a precondition for the development of an allergy. Today, knowledge of environmental factors that can alter genes or the transcription of genes in the cells has improved ${ }^{(3)}$. Grass pollens are one of the most important airborne allergen sources worldwide. About 20 species from five subfamilies are considered the most frequent causes of grass pollen allergy, and the allergenic relationships among them closely follow their phylogenetic relationships ${ }^{(4)}$.

The allergic immune response to pollen of several grass species has been studied extensively over more than three decades. Eleven groups of allergens have been identified and described, in most cases from more than one species. The allergens range from 6 to $60 \mathrm{kD}$ in apparent molecular weight and display a variety of physicochemical properties and structures ${ }^{(5)}$. Grass pollens are amongst the most clinically important allergen sources worldwide and are responsible for triggering allergic rhinitis and exacerbating asthma ${ }^{(6)}$. The most complete set of Timothy 
grass allergens has so far been isolated and cloned from Phleum pratense pollen ${ }^{(7)}$.

\section{AIM OF THE WORK}

We aimed to investigate the rate of sensitization to Timothy grass pollen in a group of asthmatic Egyptian children in relation to other markers of disease expression. Our ultimate objective was to add information to the map of aeroallergen sensitization in our country.

\section{PATIENTS AND METHODS}

This analytical cross sectional study was conducted on children with bronchial asthma following up at the Pediatric Allergy and Immunology Clinic, Children's Hospital, Ain Shams University in the period from September 2017 to March 2018. The sample included 100 asthmatic patients who were enrolled consecutively. Patients were classified into intermittent and persistent Asthma according to the 2009 VA/DoD asthma management guidelines. The study was approved by the Ethics Board of Ain Shams University.

\section{Inclusion criteria:}

- Physician diagnosed asthma.

- Age from 6 to 12 years old.

Exclusion criteria:

- Any chronic illness.

- Patients with history of recent anaphylaxis within two weeks.

\section{Methods}

The study gained approval from the local Ethics' Committee of the Department of Pediatrics, Faculty of Medicine, Ain Shams RESULTS
University. Informed consent was taken from the parents or caregivers of each patient before enrolment. All children enrolled in the study were subjected to the following:

\section{Clinical history taking with special emphasis} on:

- Medication history

- Duration of illness.

- Other concomitant allergic disorders.

- Family history of allergy.

- History of other sensitizations

- Exclusion of contraindications for current testing such as anaphylaxis or H1 antihistamine therapy

\section{Physical examination including:}

- General examination to exclude other illness

- Chest examination for current manifestations

- Other systems: nose (for allergic rhinitis) and skin (for eczema, hives or dermographism).

Investigations: Skin prick test for Timothy grass pollen, positive histamine control, negative control. (Kits from Omega - Allergy Overseas consultants Inc. - Egypt - Canada).

\section{Statistical analysis}

Data were collected, revised, coded and entered to the Statistical Package for Social Science (IBM SPSS) version 23. The quantitative data were presented as mean, standard deviations and ranges when their distribution found parametric and median with interquartile range when their distribution found non-parametric. In addition, qualitative variables were presented as number and percentages.

Table (1): Variation of TGP sensitization according to some demographic and clinical data

\begin{tabular}{|c|c|c|c|c|c|c|}
\hline & Sensitization & No sensitization & \multirow{2}{*}{$\begin{array}{c}\text { Test } \\
\text { value }\end{array}$} & \multirow{2}{*}{ p-value } & \multirow{2}{*}{ Sig. } \\
\hline & & No. $=61$ & No. $=39$ & & & \\
\hline Age in months & $\begin{array}{l}\text { Mean } \pm \text { SD } \\
\text { Range }\end{array}$ & $\begin{array}{c}104.66 \pm 22.89 \\
72-144\end{array}$ & $\begin{array}{c}106.46 \pm 29.03 \\
72-144\end{array}$ & $-0.346 \bullet$ & 0.730 & NS \\
\hline $\begin{array}{l}\text { Duration of asthma } \\
\text { in months }\end{array}$ & $\begin{array}{l}\text { Median (IQR) } \\
\text { Range }\end{array}$ & $\begin{array}{c}64(24-82) \\
12-138\end{array}$ & $\begin{array}{c}72(60-96) \\
12-141\end{array}$ & $-1.792 \ddagger$ & 0.073 & NS \\
\hline Sex & $\begin{array}{l}\text { Male } \\
\text { Female }\end{array}$ & $\begin{array}{l}37(56.0 \%) \\
24(70.6 \%)\end{array}$ & $\begin{array}{l}29(44.0 \%) \\
10(29.4 \%)\end{array}$ & $1.991^{*}$ & 0.158 & NS \\
\hline Residency & $\begin{array}{l}\text { Urban } \\
\text { Suburban } \\
\text { Rural }\end{array}$ & $\begin{array}{c}5(73.8 \%) \\
10(16.4 \%) \\
6(9.8 \%)\end{array}$ & $\begin{array}{c}23(59.0 \%) \\
12(30.8 \%) \\
4(10.3 \%)\end{array}$ & $3.005^{*}$ & 0.223 & NS \\
\hline Family history of asthma & $\begin{array}{l}\text { Yes } \\
\text { No }\end{array}$ & $\begin{array}{c}61(100.0 \%) \\
0(0.0 \%)\end{array}$ & $\begin{array}{c}39(100.0 \%) \\
0(0.0 \%)\end{array}$ & NA & NA & NA \\
\hline
\end{tabular}

P-value > 0.05: Non significant; P-value < 0.05: Significant; P-value < 0.01: Highly significant

*: Chi-square test; $\bullet$ : Independent t-test; $\ddagger$ : Mann-Whitney test 
Table (1) showed variation of TGP sensitization status in our asthmatic children according to the presence or absence of other allergic manifestations. Children with concomitant allergic rhinitis, urticaria/angioedema or eczema had sensitization frequency levels comparable to those with asthma alone.

Table (2): Influence of TGP sensitization on therapeutic modalities.

\begin{tabular}{|c|c|c|c|c|c|c|}
\hline & Sensitization & No Sensitization & \multirow{2}{*}{ Test value } & \multirow{2}{*}{ p-value } & \multirow{2}{*}{ Sig. } \\
\hline & & No. $=61$ & No. $=39$ & & & \\
\hline Nasal steroids & $\begin{array}{l}\text { Yes } \\
\text { No }\end{array}$ & $\begin{array}{l}36(59.0 \%) \\
25(41.0 \%)\end{array}$ & $\begin{array}{l}20(51.3 \%) \\
19(48.7 \%)\end{array}$ & $0.578 *$ & 0.447 & NS \\
\hline As-needed reliever & $\begin{array}{l}\text { Yes } \\
\text { No }\end{array}$ & $\begin{array}{c}52(85.2 \%) \\
9(14.8 \%)\end{array}$ & $\begin{array}{c}34(87.2 \%) \\
5(12.8 \%) \\
\end{array}$ & $0.074 *$ & 0.786 & NS \\
\hline low-dose ICS & $\begin{array}{l}\text { Yes } \\
\text { No }\end{array}$ & $\begin{array}{l}24(39.3 \%) \\
37(60.7 \%) \\
\end{array}$ & $\begin{array}{l}22(56.4 \%) \\
17(43.6 \%) \\
\end{array}$ & $2.789 *$ & 0.095 & NS \\
\hline Medium-dose ICS & $\begin{array}{l}\text { Yes } \\
\text { No }\end{array}$ & $\begin{array}{l}13(21.3 \%) \\
48(78.7 \%)\end{array}$ & $\begin{array}{l}11(28.2 \%) \\
28(71.8 \%)\end{array}$ & $0.620 *$ & 0.431 & NS \\
\hline High-dose ICS & $\begin{array}{l}\text { Yes } \\
\text { No }\end{array}$ & $\begin{array}{l}12(19.7 \%) \\
49(80.3 \%)\end{array}$ & $\begin{array}{c}2(5.1 \%) \\
37(94.9 \%)\end{array}$ & $4.180^{*}$ & 0.041 & S \\
\hline LABA & $\begin{array}{l}\text { Yes } \\
\text { No }\end{array}$ & $\begin{array}{c}0(0.0 \%) \\
61(100.0 \%)\end{array}$ & $\begin{array}{c}0(0.0 \%) \\
39(100.0 \%)\end{array}$ & NA & NA & NA \\
\hline LRA & $\begin{array}{l}\text { Yes } \\
\text { No }\end{array}$ & $\begin{array}{l}22(36.1 \%) \\
39(63.9 \%)\end{array}$ & $\begin{array}{c}6(15.4 \%) \\
33(84.6 \%)\end{array}$ & $5.047 *$ & 0.025 & $S$ \\
\hline
\end{tabular}

P-value > 0.05: Non significant; P-value < 0.05: Significant; P-value < 0.01: Highly significant; *: Chi-square test ICS: inhaled corticosteroids, LABA: Long acting Beta 2 agonist, LRA: Leukotriene receptor antagonist.

A statistically significant increase in the need for high-dose inhaled corticosteroids $(\mathrm{p}=0.041)$ and for add-on therapy with leukotriene receptor antagonist $(\mathrm{p}=0.025)$ was observed in patients with TGP sensitization as compared to non-sensitized children (table 2).

Table (3): Variation of sensitization status according to asthma type

\begin{tabular}{|c|c|c|c|c|c|c|}
\hline & Sensitization & No Sensitization & \multirow{2}{*}{ Test value } & \multirow{2}{*}{ p-value } & \multirow{2}{*}{ Sig. } \\
\hline & & No. $=61$ & No. $=39$ & & & \\
\hline Asthma class & $\begin{array}{l}\text { Intermittent } \\
\text { Persistent }\end{array}$ & $\begin{array}{l}12(19.7 \%) \\
49(80.3 \%)\end{array}$ & $\begin{array}{c}4(10.3 \%) \\
35(89.7 \%)\end{array}$ & $1.569^{*}$ & 0.210 & $\mathrm{NS}$ \\
\hline
\end{tabular}

P-value > 0.05: Non significant; P-value < 0.05: Significant; P-value < 0.01: Highly significant

*: Chi-square test; :: Mann-Whitney test

Patients with persistent asthma were more prone to be TGP sensitized $(80.3 \%)$ than those with intermittent asthma (19.7\%). However, the comparison in each group did not reach statistical significance. Noteworthy, patients with intermittent asthma in the current study represented only $16 \%$ (table 3 ).

Table (4): Variation of TGP wheal diameter according to the coexistence of other allergies

\begin{tabular}{|c|c|c|c|c|c|c|}
\hline & & \multicolumn{2}{|c|}{ Asthma } & \multirow{3}{*}{ Test value } & \multirow{3}{*}{ p-value } & \multirow{3}{*}{ Sig. } \\
\hline & & Alone & With others & & & \\
\hline & & No. $=8$ & No. $=53$ & & & \\
\hline $\begin{array}{l}\text { Diameter of wheal } \\
\text { in sensitized patients }(\mathrm{mm})\end{array}$ & $\begin{array}{l}\text { Median (IQR) } \\
\text { Range }\end{array}$ & $\begin{array}{c}3.5(3-4) \\
3-4\end{array}$ & $\begin{array}{c}4(3-4) \\
3-7\end{array}$ & $-0.571 \neq$ & 0.568 & NS \\
\hline
\end{tabular}

P-value > 0.05: Non significant; P-value < 0.05: Significant; P-value < 0.01: Highly significant

*: Chi-square test; ¥: Mann-Whitney test

Sensitized children with asthma alone showed smaller wheal diameters (median $=3.5$ $\mathrm{mm}$, range: $3-4 \mathrm{~mm}$ ) than those with concomitant allergies who showed larger diameter (median= $4 \mathrm{~mm}$, range: $3-7 \mathrm{~mm}$ ).
However, the comparison within each group did not reach statistical significance. Worth mentioning, children with asthma alone in the current study represented only $13.1 \%$ of all sensitized children. 


\section{DISCUSSION}

The increase in allergies is a phenomenon that is being observable in all developing countries including the African continent. Grass pollens are amongst the most clinically important allergen sources worldwide and are responsible for triggering allergic rhinitis and exacerbating asthma ${ }^{(6)}$. The most complete set of Timothy grass allergens has so far been isolated and cloned from Phleum pratense pollen ${ }^{(7)}$.

The current study investigated sensitization to Timothy grass pollen in a group of asthmatic Egyptian children in relation to other markers of disease expression aiming at recognition of this allergen as a potential cause of pediatric asthma in our country ${ }^{(8,9)}$.

The results revealed a high frequency of Timothy Grass Pollen (TGP) sensitization representing $61 \%$ of the studied sample which was higher than the figures reported from Tehran, Iran being $30.6 \%{ }^{(\mathbf{1 0}, \mathbf{1 1})}$, Guangzhou, southern China being 14\% in children aged $<14$ years ${ }^{(\mathbf{1 2})}$, and Changhua, Taiwan being only $12.3 \%{ }^{(13)}$. On the other hand, Pendino et al. (14) reported a total rate of pollen sensitization of $52 \%$ in children aged 5-10 years in the city of Rosario, Argentina.

The high rates of TGP sensitization in the current study might reflect the physiciandiagnosed nature of the sample in which aeroallergen sensitization is quite expected. Population based studies would yield lower rates of sensitization as seen from studies in other geographic locations. Worth mentioning is that none of our subjects had wheal diameter $\geq 8 \mathrm{~mm}$ which predicts actual allergy to timothy grass. This means that our children were sensitized rather than allergic and the observation is limited indeed by the sample size.

The frequency of sensitization to TGP in males in our series was $56 \%$ while in females it was $70.6 \%$ with no significant difference in between. Figures reported by Luo et al. ${ }^{(\mathbf{1 2})}$ were $13.9 \%$ in males and $13.1 \%$ in females denoting no gender difference.

Children with exclusive asthma and no concomitant allergies in our series showed a TGP sensitization rate of $13.1 \%$ which agreed with $\mathbf{L u o}$ et al. ${ }^{(12)}$ who found that $14.1 \%$ of their asthma alone patients were sensitized to TGP. On the other hand, $60.2 \%$ of our children with asthma and concomitant allergic rhinitis were sensitized to TGP unlike the sensitization rate in the study of Luo et al. ${ }^{(12)}$ which was only $15.9 \%$. However, the latter study noted that TGP sensitized patients were more prone to develop asthma with concomitant allergic rhinitis than to develop asthma alone.

In our series, the wheal diameter in asthmatic patients with concomitant allergies (median $=4 \mathrm{~mm}$, range: $3-7 \mathrm{~mm}$ ) seemed higher than that of children with asthma alone (median $=3.5 \mathrm{~mm}$, range: $3-4 \mathrm{~mm}$ ). However, the difference did not reach statistical significance indicating that the coexistence of other allergies is not dependent on the concentration of TGP specific IgE.

In our study, Patients with persistent asthma were more prone to be TGP-sensitized $(80.3 \%)$ than those with intermittent asthma $(19.7 \%)$. This may denote that TGP sensitization, as many other aeroallergens, could be a risk factor for persistence of asthma symptoms.

Moreover, a statistically significant increase in the need for high-dose inhaled corticosteroids ( $p=0.041)$ and for add-on therapy with leukotriene receptor antagonist $(p=0.025)$ was observed in patients with TGP sensitization as compared to those without, which again points to a potential link to asthma severity in these children. Our observation agreed with that of Wickman et al. ${ }^{(15)}$ who noted that IgE reactivity early in life to some allergens including birch and timothy grass pollen as well as from cat and peanut is associated with $95 \%$ predictive risk of airway allergy persistence through adolescence in a Swedish setting. However, this came in contrast to the results of Perečinský et al. ${ }^{(16)}$ who found that pollen allergy in general is associated with mild bronchial hyperresponsiveness and intermittent asthma and with low risk of developing moderate to severe bronchial hyper-responsiveness.

We observed a higher rate of concomitant urticaria/angioedema $(p=0.002)$ in children with intermittent asthma as compared to those with persistent asthma. It was assumed that some triggers of urticarial episodes such as infections, drugs and food could be common potential triggers of acute intermittent exacerbations of intermittent asthma $^{(18,17)}$. 
The most important limitation of our study was the small sample size, which hindered exact interpretation of the sensitization status in our expanding community. Another limitation was the executive manner of sample recruitment which led to unequal distribution of the study variables such as the gender and location of allergic manifestations. For instance, patients with asthma alone represented only $10 \%$ while patients with concomitant allergies represented $90 \%$ of our series. Similarly, patients with persistent asthma comprised a larger sector (84\%) of our population. These factors would represent an analytic bias in data interpretation.

\section{CONCLUSION}

Sensitization to Timothy grass pollen (TGP) might point to a persistent phenotype of pediatric asthma and may be linked to severity and need to step up and/or add on therapeutic options.

\section{REFERENCES}

1- Da Silva ES, Asam C, Lackner P, Hofer H, Wallner M, Pinheiro CS, Alcântara-Neves NM, Ferreira F (2017): Allergens of Blomia tropicalis: An Overview of Recombinant Molecules. Int Arch Allergy Immunol., 172(4): 203-14.

2- Salo P, Arbes S, Jaramillo R, Calatroni A, Weir C, Sever M et al. (2014): Prevalence of allergic sensitization in the United States: Results from the National Health and Nutrition Examination Survey (NHANES) 2005-2006. J Allergy Clin Immunol., 134: 350-9.

3- Lake I, Jones N, Agnew M, Goodess C, Giorgi F, Hamaoui-Laguel $\mathrm{L}$ et al. (2016): Climate Change and Future Pollen Allergy in Europe. Env Health Pers, 125: 420-5.

4- D'Amato G, Cecchi L, Bonini S, Nunes C, Annesi-Maesano I, Behrendt $\mathrm{H}$ et al. (2007): Allergenic pollen and pollen allergy in Europe. Allergy, 62(9): 97690.

5- Andersson K, Lidholm J (2014): Characteristics and immunobiology of grass pollen allergens. Int Arch Allergy Immunol., 130: 87-107.
6- Davies JM (2014): Grass pollen allergens globally: the contribution of subtropical grasses to burden of allergic respiratory diseases. Clin Exp Allergy, 44: 790-801.

7- Hatzler L, Panetta V, Lau S, Wagner P, Bergmann R, Illi $S$ et al. (2012): Molecular spreading and predictive value of preclinical $\operatorname{IgE}$ response to Phleum pratense in children with hay fever. J Allergy Clin Immunol., 130: 894-901.

8- Wheatley LM, Togias A (2015): Allergic rhinitis. N Engl J Med., 372: 456-63.

9- Pavord ID, Beasley R, Agusti A, Anderson GP, Bel E, Brusselle G et al. (2017): After asthma: redefining airways diseases, 120: 420-6.

10- Wenzel SE (2004): Phenotypes in asthma: useful guides for therapy, distinct biological processes, or both Am J Respir Crit Care Med., 170:579-580.

11- Shoormasti RS, Pourpak Z, Fazlollahi MR, Shabani A, Kazemnejad A, Ebadi Z, Moin M (2017): Determination of the most common indoor and outdoor allergens in 602 patients with allergic symptoms using specific ige local panel. Iran J Allergy, Asthma and Immunol., 16(4): 298.

12- Luo W, Huang H, Zheng P, Wei N, Luo J, Sun B, Zeng G (2016): Major grass pollen allergens and components detected in a southern Chinese cohort of patients with allergic rhinitis and/or asthma. Molecular Immunology,78:105-12.

13- Yong SB, Wu CC, Tzeng YC, Hung WC, Yang KD (2013): Different profiles of allergen sensitization in different ages and geographic areas in Changhua, Taiwan. Journal of Microbiology, Immunology and Infection, 46(4):295-301.

14- Pendino $P$, Agüero $C$, Cavagnero $P$, Lopez K, Kriunis I, Molinas $\mathbf{J}$ (2011): Aeroallergen sensitization in wheezing children from rosario, Argentina. World Allergy Organization Journal, 4(10):159. 
15- Wickman M, Lupinek C, Andersson N, Belgrave D, Asarnoj A, Benet $\mathrm{M}$ et al. (2017): Detection of $\operatorname{IgE}$ reactivity to a handful of allergen molecules in early childhood predicts respiratory allergy in adolescence. EBioMedicine, 26:91-99.

16- Perečinský S, Varga M, Petrovičová J, Ragač $\mathbf{O}$, Perečinská $\mathrm{K}$, Jančová $\mathrm{A}$, Murínová L, Bačinský T, Legáth LU (2017): Different clinical effect of several types of airborne allergens on the severity of bronchial hyperreactivity. Wiener klinische Wochenschrift, 129(19-20):674-9.
17- Criado RF, Criado P (2018): Urticaria. InDermatology in Public Health Environments, 124:1311-37

18- Liu AH, Jaramillo R, Sicherer SH, Wood RA, Bock SA, Burks AW et al. (2010): National prevalence and risk factors for food allergy and relationship to asthma: results from the National Health and Nutrition Examination Survey 2005-2006. J Allergy Clin Immunol., 126(4):798806. 